\title{
Melanocytes and Their Diseases
}

\author{
Yuji Yamaguchi ${ }^{1}$ and Vincent J. Hearing ${ }^{2}$ \\ ${ }^{1}$ Medical, AbbVie GK, Mita, Tokyo 108-6302, Japan \\ ${ }^{2}$ Laboratory of Cell Biology, National Cancer Institute, National Institutes of Health, Bethesda, Maryland 20892 \\ Correspondence: hearingv@nih.gov
}

Human melanocytes are distributed not only in the epidermis and in hair follicles but also in mucosa, cochlea (ear), iris (eye), and mesencephalon (brain) among other tissues. Melanocytes, which are derived from the neural crest, are unique in that they produce eu-/pheomelanin pigments in unique membrane-bound organelles termed melanosomes, which can be divided into four stages depending on their degree of maturation. Pigmentation production is determined by three distinct elements: enzymes involved in melanin synthesis, proteins required for melanosome structure, and proteins required for their trafficking and distribution. Many genes are involved in regulating pigmentation at various levels, and mutations in many of them cause pigmentary disorders, which can be classified into three types: hyperpigmentation (including melasma), hypopigmentation (including oculocutaneous albinism [OCA]), and mixed hyper-/hypopigmentation (including dyschromatosis symmetrica hereditaria). We briefly review vitiligo as a representative of an acquired hypopigmentation disorder.

$\mathrm{P}^{\mathrm{i}}$ gments that determine human skin colors include melanin, hemoglobin (red), hemosiderin (brown), carotene (yellow), and bilin (yellow). Among those, melanins play key roles in determining human skin (and hair) pigmentation. Melanin pigments can be classified into two major types based on their biosynthetic pathways, as updated and reviewed elsewhere: eumelanin (dark brown and black) and pheomelanin (yellow, red, and light brown) (Simon et al. 2009; Hearing 2011; Kondo and Hearing 2011). Eu-/pheo-melanin pigments are produced and deposited in melanosomes, which belong to the LRO (lysosome-related organelle) family in that they contain acid-dependent hydrolases and lysosomal-associated membrane proteins (Raposo and Marks 2007). Melano- somes can be divided into four stages depending on their degree of maturation. Early melanosomes, especially stage I melanosomes, are similar to lysosomes whereas late melanosomes contain a structured matrix and highly dense melanin deposits. Studies of melanosomes are not only performed in medicine but also in archaeology because various morphologies of melanosomes remaining in fossils serve as clues to hypothesize the colors of dinosaurs ( $\mathrm{Li}$ et al. 2012).

Melanocytes can be defined as cells that possess the unique capacity to synthesize melanins within melanosomes. Factors related to melanin production within melanocytes can be divided into three groups as previously reviewed: structural proteins of melanosomes, enzymes

Editors: Anthony E. Oro and Fiona M. Watt

Additional Perspectives on The Skin and Its Diseases available at www.perspectivesinmedicine.org

Copyright (C) 2014 Cold Spring Harbor Laboratory Press; all rights reserved; doi: 10.1101/cshperspect.a017046

Cite this article as Cold Spring Harb Perspect Med 2014;4:a017046 
required for melanin synthesis, and proteins required for melanosome transport and distribution (Yamaguchi and Hearing 2009). We briefly update the recent findings regarding pigmentation-related factors.

Disruptions of the functions of many pigmentation-related factors are known to cause pigmentary disorders and a curated list of those are summarized and updated at the homepage of the European Society for Pigment Cell Research (www.espcr.org/micemut). Those disorders include hyperpigmentation, hypopigmentation, and mixed hyper-/hypopigmentation disorders, which are subdivided into congenital or acquired status (Table 1). Their diagnosis depends on the size, location (involved site(s) of the body), and morphology (isolated, multiple, map-like, reticular, or linear) of the lesions. Hypopigmentation disorders are subclassified into those associated with complete or incomplete depigmentation.

\section{MELANOCYTE DEVELOPMENT}

As recently summarized (Kawakami and Fisher 2011; Sommer 2011), melanocytes in the skin are exclusively derived from the neural crest. Melanocytes used to be thought to derive directly from neural crest cells migrating via a dorsolateral path (between the ectoderm and dermamyotome of somites) during embryogenesis, whereas neurons and glial cells were thought to derive from neural crest cells migrating via a ventral path between the neural tube and somites. Adameyko et al. (2009) recently challenged this idea and reported that melanocytes migrate and differentiate from nerve-derived Schwann cell precursors, whose fate is determined by the loss of Hmxl homeobox gene function in the ventral path. Schwann cell precursors detaching from the nerve differentiate into melanocytes, whereas precursors that stay in contact with nerves eventually differentiate into Schwann cells. Those authors also showed that Schwann cells remain competent to form melanocytes using Krox20 (early growth response 2 or Egr2)-Cre loci crossed to YFP reporter strains. They also showed that Neuregulin-1 (also known as glial growth factor,
Heregulin or Neu differentiation factor) regulates the survival and proliferation of Schwann cell precursors and determines the fate of Schwann cells and melanocytes depending on high and low expression levels, respectively, and that secreted signals, including IGF (insulin-like growth factor) and PDGF (platelet-derived growth factor) enhance melanocyte development (Adameyko et al. 2009). Those findings may explain the facts that patients with neurofibromatosis type 1 , who develop neurofibromas consisting mainly of Schwann cells, are hyperpigmented, and that segmental vitiligo mostly occurs along with the affected innervation zones or dermatomes.

Taken together, melanocytes in the skin eventually derive from the neural crest and either differentiate directly from neural crest cells via a dorsolateral path or derive from Schwann cell precursors via a ventral path after detaching from the nerve. Various transcription factors, including Hmx1 and Krox20, act as intrinsic factors that regulate the fate of these cell types, which are modulated by extrinsic factors including Neuregulin-1, IGF, and PDGF.

\section{MELANOCYTE HETEROGENEITY}

Human melanocytes reside not only in the epidermis and in hair follicles but also in mucosa, cochlea of the ear, iris of the eye, and mesencephalon of the brain as well as other tissues (Plonka et al. 2009). As far as mouse melanocytes are concerned, Aoki et al. reported that noncutaneous (ear, eye, and harderian gland) and dermal melanocytes are different from epidermal melanocytes in that the former do not respond to KIT stimulation but respond well to ET3 (endothelin 3) or HGF (hepatocyte growth factor) signals (Aoki et al. 2009), suggesting the heterogeneity of mouse melanocytes. They also reported that noncutaneous or dermal melanocytes cannot participate in regenerating follicular melanocytes using the hair reconstitution assay, unlike epidermal melanocytes (Aoki et al. 2011). Studies by Tobin's group also support the hypothesis that follicular and epidermal melanocytes in human skin are different regarding their responses to various biological response 
Melanocytes and Their Diseases

Table 1. Pigmentary disorders and possible responsive genes

\begin{tabular}{|c|c|c|c|}
\hline $\begin{array}{l}\text { Representative } \\
\text { disease }\end{array}$ & Disease brief description & Locus & Mechanism(s) of action \\
\hline \multicolumn{4}{|c|}{ Hyperpigmentation disorder } \\
\hline \multicolumn{4}{|c|}{ Congenital } \\
\hline $\begin{array}{l}\text { Generalized } \\
\text { lentiginosis }\end{array}$ & $\begin{array}{l}\text { Widespread lentigines without } \\
\text { associated noncutaneous } \\
\text { abnormalities }\end{array}$ & $\begin{array}{l}\text { Chromosome } \\
4 \mathrm{q} 21.1-\mathrm{q} 22.3\end{array}$ & \\
\hline $\begin{array}{l}\text { LEOPARD } \\
\text { syndrome }\end{array}$ & $\begin{array}{l}\text { Multiple lentigines, congenital } \\
\text { cardiac abnormalities, ocular } \\
\text { hypertelorism, and } \\
\text { retardation of growth }\end{array}$ & PTPN11 & $\begin{array}{l}\text { Protein tyrosine phosphatase, } \\
\text { nonreceptor type } 11\end{array}$ \\
\hline Carney complex & $\begin{array}{l}\text { A multiple neoplasia syndrome } \\
\text { characterized by spotty skin } \\
\text { pigmentation, cardiac and } \\
\text { other myxomas, endocrine } \\
\text { tumors, and psammomatous } \\
\text { melanotic schwannomas }\end{array}$ & PRKAR1A & $\begin{array}{l}\text { Protein kinase A regulatory } \\
\quad \text { subunit } 1 \alpha\end{array}$ \\
\hline $\begin{array}{l}\text { Peutz-Jeghers } \\
\text { syndrome }\end{array}$ & $\begin{array}{l}\text { Pigments on lips and } \\
\text { palmoplantar area }\end{array}$ & STK11/LKB1 & Serine/threonine kinase 11 \\
\hline
\end{tabular}

\section{Others}

Nevus cell nevus, Spitz nevus, Nevus spilus, blue nevus, nevus Ohta, dermal melanosis, nevus Ito, Mongolian spot, ephelides, acropigmentio reticularis, Spitzenpigment/acropigmentation, inherited patterned lentiginosis, Laugier-Hunziker-Baran syndrome, Cronkhite-Canada syndrome

Others

Senile lentigines/lentigo, Riehl's melanosis, labial melanotic macule, penile/vulvovaginal melanosis, erythromelanosis follicularis faciei (Kitamura), pigmentation petaloides actinica tanning, postinflammatory pigmentation, chemical/drug-induced pigmentation, pigmentary demarcation lines, foreign material deposition

Hyperpigmentation related with systemic disorders and others

\begin{tabular}{|c|c|c|c|}
\hline Mastocytosis & Darier's sign & KIT and others & Urticaria pigmentosa \\
\hline $\begin{array}{l}\text { Neurofibromatosis } \\
\text { type } 1\end{array}$ & $\begin{array}{l}\text { Neurofibromas and café-au-lait } \\
\text { spots/von Recklinghausen's } \\
\text { disease }\end{array}$ & NF1 & $\begin{array}{l}\text { RAS GTPase-activating protein; } \\
\text { Neurofibromin } 1\end{array}$ \\
\hline Sotos syndrome & $\begin{array}{l}\text { Tall stature, advanced bone age, } \\
\text { typical facial abnormalities, } \\
\text { and developmental delay }\end{array}$ & NSD1 & $\begin{array}{l}\text { Nuclear receptor binding SET } \\
\text { domain protein } 1\end{array}$ \\
\hline POEMS syndrome & $\begin{array}{l}\text { Polyneuropathy, organomegaly, } \\
\text { endocrinopathy, M-protein, } \\
\text { and skin changes }\end{array}$ & $\begin{array}{l}\text { VEGF and } \\
\text { others }\end{array}$ & $\begin{array}{l}\text { Vascular endothelial growth factor } \\
\text { and angiogenetic factors }\end{array}$ \\
\hline Cantu syndrome & $\begin{array}{l}\text { Hypertrichosis, macrosomia, } \\
\text { osteochondrodysplasia, and } \\
\text { cardiomegaly }\end{array}$ & ABCC9 & $\begin{array}{l}\text { ATP-binding cassette, subfamily C, } \\
\text { member } 9\end{array}$ \\
\hline $\begin{array}{l}\text { McCune-Albright } \\
\text { syndrome }\end{array}$ & $\begin{array}{l}\text { Clinical triad of fibrous dysplasia } \\
\text { of bone, cafe-au-lait skin spots, } \\
\text { and precocious puberty }\end{array}$ & GNAS & $\begin{array}{l}\text { Guanine nucleotide-binding } \\
\text { protein, } \alpha \text { stimulation/ } \\
\text { stimulatory G protein }\end{array}$ \\
\hline Bloom syndrome & $\begin{array}{l}\text { Photosensitivity and increased } \\
\text { risk of malignancy }\end{array}$ & BLM & RecQ helicase family \\
\hline
\end{tabular}


Y. Yamaguchi and V.J. Hearing

Table 1. Continued

\begin{tabular}{|c|c|c|c|}
\hline $\begin{array}{l}\text { Representative } \\
\text { disease }\end{array}$ & Disease brief description & Locus & Mechanism(s) of action \\
\hline \multicolumn{4}{|l|}{ Others } \\
\hline \multicolumn{4}{|c|}{$\begin{array}{l}\text { Naegeli syndrome, Watson syndrome, metabolism/enzyme disorders, endocrine disorders, nutritional } \\
\text { disorders, collagen diseases, liver dysfunction, kidney dysfunction, infectious diseases }\end{array}$} \\
\hline \multicolumn{4}{|c|}{ Hypopigmentation disorder } \\
\hline \multicolumn{4}{|c|}{ Congenital } \\
\hline $\begin{array}{l}\text { Oculocutaneous } \\
\text { albinism type } 1\end{array}$ & Hypopigmentation, nystagmus & TYR GPR143 & $\begin{array}{l}\text { Melanosomal enzyme G-protein- } \\
\text { coupled receptor (GPR143); } \\
\text { melanosome biogenesis signal } \\
\text { transduction }\end{array}$ \\
\hline $\begin{array}{l}\text { Oculocutaneous } \\
\text { albinism type } 2\end{array}$ & & OCA2 & Melanosome biogenesis and size \\
\hline $\begin{array}{l}\text { Oculocutaneous } \\
\text { albinism type } 3\end{array}$ & & TYRP1 & $\begin{array}{l}\text { Melanosomal enzyme; stabilizing } \\
\text { factor }\end{array}$ \\
\hline $\begin{array}{l}\text { Oculocutaneous } \\
\text { albinism type } 4\end{array}$ & & SLC45A2 & $\begin{array}{l}\text { Solute transporter; previously } \\
\text { named as membrane-associated } \\
\text { transporter protein (MATP) }\end{array}$ \\
\hline $\begin{array}{l}\text { Hermansky-Pudlak } \\
\text { syndrome type } 1\end{array}$ & $\begin{array}{l}\text { Hypopigmentation, bleeding } \\
\text { caused by thrombopenia }\end{array}$ & HPS1 & $\begin{array}{l}\text { Membrane protein; organelle } \\
\text { biogenesis and size }\end{array}$ \\
\hline $\begin{array}{l}\text { Hermansky-Pudlak } \\
\text { syndrome type } 2\end{array}$ & & AP3B1 & $\begin{array}{l}\beta 3 \text { Subunit of adaptor protein } 3 \\
\text { complex; organellar protein } \\
\text { routing }\end{array}$ \\
\hline $\begin{array}{l}\text { Hermansky-Pudlak } \\
\text { syndrome type } 3\end{array}$ & & HPS3 & Organelle biogenesis \\
\hline $\begin{array}{l}\text { Hermansky-Pudlak } \\
\text { syndrome type } 4\end{array}$ & & HPS4 & Organelle biogenesis and size \\
\hline $\begin{array}{l}\text { Hermansky-Pudlak } \\
\text { syndrome type } 5\end{array}$ & & HPS5 & $\begin{array}{l}\text { Biogenesis of lysosome-related } \\
\text { organelles complex-2 }\end{array}$ \\
\hline $\begin{array}{l}\text { Hermansky-Pudlak } \\
\text { syndrome type } 6\end{array}$ & & HPS6 & $\begin{array}{l}\text { Biogenesis of lysosome-related } \\
\text { organelles complex- } 2\end{array}$ \\
\hline $\begin{array}{l}\text { Hermansky-Pudlak } \\
\text { syndrome type } 7\end{array}$ & & DTNBP1 & $\begin{array}{l}\text { Dysbindin, component of the } \\
\text { biogenesis of lysosome-related } \\
\text { organelles complex-1 (BLOC1) }\end{array}$ \\
\hline $\begin{array}{l}\text { Hermansky-Pudlak } \\
\text { syndrome type } 8\end{array}$ & & BLOC1S3 & $\begin{array}{l}\text { Component of the } \mathrm{BLOC} 1 \text { protein } \\
\text { transport complex }\end{array}$ \\
\hline $\begin{array}{l}\text { Hermansky-Pudlak } \\
\text { syndrome type } 9\end{array}$ & & PLDN & Vesicle-docking and fusion \\
\hline $\begin{array}{l}\text { Chediak-Higashi } \\
\text { syndrome }\end{array}$ & $\begin{array}{l}\text { Hypopigmentation, infection } \\
\text { caused by immunodeficiency }\end{array}$ & LYST & $\begin{array}{l}\text { Organelle biogenesis and size; } \\
\text { membrane protein }\end{array}$ \\
\hline $\begin{array}{l}\text { Griscelli syndrome } \\
\quad \text { type } 1\end{array}$ & $\begin{array}{l}\text { Hypopigmentation, } \\
\text { hepatosplenomegaly, } \\
\text { pancytopenia, immunologic } \\
\text { disorder, and central nervous } \\
\text { system abnormalities }\end{array}$ & MYO5A & $\begin{array}{l}\text { Melanosome transport; myosin } \\
\text { type Va/dilute mice }\end{array}$ \\
\hline $\begin{array}{l}\text { Griscelli syndrome } \\
\text { type } 2\end{array}$ & & RAB27A & $\begin{array}{l}\text { Melanosome transport; RAS- } \\
\text { associated protein/ashen mice }\end{array}$ \\
\hline $\begin{array}{l}\text { Griscelli syndrome } \\
\text { type } 3\end{array}$ & & MLPH & $\begin{array}{l}\text { Melanosome transport; } \\
\text { melanophilin/leaden mice }\end{array}$ \\
\hline Phenylketonuria & $\begin{array}{l}\text { Phenylalanine hydroxylase } \\
\text { deficiency }\end{array}$ & $\mathrm{PAH}$ & Phenylalanine hydroxylase \\
\hline
\end{tabular}


Melanocytes and Their Diseases

Table 1. Continued

\begin{tabular}{|c|c|c|c|}
\hline $\begin{array}{l}\text { Representative } \\
\text { disease }\end{array}$ & Disease brief description & Locus & Mechanism(s) of action \\
\hline Piebaldism & $\begin{array}{l}\text { White spotting, megacolon, and } \\
\text { other neural crest defects }\end{array}$ & KIT & $\begin{array}{l}\text { Receptor for SCF; required for } \\
\text { melanoblast survival and } \\
\text { homing }\end{array}$ \\
\hline $\begin{array}{l}\text { Waardenburg } \\
\text { syndrome type } 1 \\
\text { and } 3\end{array}$ & $\begin{array}{l}\text { White spotting and small or } \\
\text { absent eyes }\end{array}$ & PAX3 & $\begin{array}{l}\text { Transcription factor; neural tube } \\
\text { development }\end{array}$ \\
\hline $\begin{array}{l}\text { Waardenburg } \\
\text { syndrome type } 2\end{array}$ & $\begin{array}{l}\text { White spotting, head blaze, pale } \\
\text { hair and skin, neural crest, } \\
\text { and other organ defects }\end{array}$ & MITF SNAI2 & $\begin{array}{l}\text { Transcription factor; master } \\
\text { regulator of melanocyte lineage } \\
\text { transcription factor }\end{array}$ \\
\hline $\begin{array}{l}\text { Waardenburg-Shah } \\
\text { syndrome }\end{array}$ & $\begin{array}{l}\text { White spotting, megacolon, and } \\
\text { other neural crest defects }\end{array}$ & EDN3 SOX10 & $\begin{array}{l}\text { Melanoblast/neuroblast growth } \\
\text { and differentiation factor; } \\
\text { transcription factor }\end{array}$ \\
\hline $\begin{array}{l}\text { Hypomelanosis of } \\
\text { Ito }\end{array}$ & $\begin{array}{l}\text { Hypopigmentation along } \\
\text { Blaschko lines/neural } \\
\text { disorders }\end{array}$ & $\begin{array}{l}\text { Duplication of } \\
\text { Xp11.3- } \\
\text { p11.4 and } \\
\text { random X } \\
\text { inactivation }\end{array}$ & \\
\hline $\begin{array}{l}\text { Hirschsprung's } \\
\text { disease type } 2\end{array}$ & $\begin{array}{l}\text { White spotting, megacolon, and } \\
\text { other neural crest defects }\end{array}$ & EDNRB & Endothelin receptor B \\
\hline Fraser syndrome & $\begin{array}{l}\text { Microphthalmia/anophthalmia, } \\
\text { patches of discolored or white } \\
\text { fur }\end{array}$ & FREM2 & $\begin{array}{l}\text { Extracellular protein related with } \\
\text { epithelial-mesenchymal } \\
\text { interactions }\end{array}$ \\
\hline $\begin{array}{l}\text { Charcot-Marie- } \\
\text { Tooth disease } \\
\text { type } 4 \mathrm{~J}\end{array}$ & $\begin{array}{l}\text { Pale skin, alopecia, clumped } \\
\text { melanosomes, and immune } \\
\text { effects }\end{array}$ & FIG4 & $\begin{array}{l}\text { Phosphatidylinositol-(3,5)- } \\
\text { bisphosphatase 5-phosphatase; } \\
\text { late endosome-lysosome axis }\end{array}$ \\
\hline Menkes disease & $\begin{array}{l}\text { Copper transport disorders, } \\
\text { kinky hair }\end{array}$ & ATP7A & $\begin{array}{l}\text { ATPase, copper-transporting } \alpha \\
\text { polypeptide }\end{array}$ \\
\hline Wilson disease & $\begin{array}{l}\text { Copper transport disorders, } \\
\text { kinky hair }\end{array}$ & ATP7B & $\begin{array}{l}\text { ATPase, copper-transporting } \beta \\
\text { polypeptide }\end{array}$ \\
\hline Cystinosis & $\begin{array}{l}\text { Multiple organ dysfuctions } \\
\text { caused by cystine crystal } \\
\text { accumulation }\end{array}$ & CTNS & $\begin{array}{l}\text { Cystinosin, cysteine } / \mathrm{H}^{+} \\
\text {symporter, which exports } \\
\text { cysteine out of lysosomes }\end{array}$ \\
\hline \multicolumn{4}{|c|}{$\begin{array}{l}\text { Others } \\
\text { Cross-McKusick-Breen syndrome, nevus depigmentosus }\end{array}$} \\
\hline \multicolumn{4}{|c|}{ Acquired } \\
\hline Vitiligo & $\begin{array}{l}\text { Lesions depigmented completely } \\
\text { at initiation phase and } \\
\text { pigmented orifices of hair } \\
\text { follicles at recovering phase } \\
\text { and hyperpigmented ridges } \\
\text { surrounded by the lesion at } \\
\text { stable/intractable phase }\end{array}$ & $\begin{array}{l}\text { NALP1 MHCI } \\
\text { MHCII } \\
\text { PTPN22 LPP } \\
\text { IL2RA } \\
\text { UBASH3A } \\
\text { C1QTNF6 } \\
\text { RERE } \\
\text { GZMB } \\
\text { FOXP1 } \\
\text { CCR6 } \\
\text { and others }\end{array}$ & $\begin{array}{l}\text { NLR family, pyrin domain } \\
\text { containing 1/major- } \\
\text { histocompatibility-complex } \\
\text { class I molecules and class II } \\
\text { molecules/protein tyrosine } \\
\text { phosphatase, nonreceptor type } \\
\text { 22/LIM domain containing } \\
\text { preferred translocation partner } \\
\text { in lipoma/ubiquitin associated } \\
\text { and SH3 domain containing A/ } \\
\text { C1q and tumor-necrosis-factor- } \\
\text { related protein } 6 \text { gene/arginine- } \\
\text { glutamic acid dipeptide repeats/ } \\
\text { granzyme B }\end{array}$ \\
\hline
\end{tabular}


Y. Yamaguchi and V.J. Hearing

Table 1. Continued

\begin{tabular}{lccc}
\hline $\begin{array}{l}\text { Representative } \\
\text { disease }\end{array}$ & Disease brief description & Locus & Mechanism(s) of action \\
\hline $\begin{array}{l}\text { Vogt-Koyanagi- } \\
\text { Harada disease }\end{array}$ & $\begin{array}{c}\text { Bilateral, chronic, diffuse } \\
\text { granulomatous uveitis with } \\
\text { poliosis, vitiligo, central } \\
\end{array}$ & $\begin{array}{c}\text { HLA-D IL17 } \\
\text { nervous system, and auditory }\end{array}$ & HLA-D gene locus including HLA- \\
& & DRB1, DR1, DR4, DQA1, and \\
& signs & DQB1/interleukin-17
\end{tabular}

Others

Sutton nevus/phenomenon, malignancy-induced hypopigmentation, postinflammatory hypopigmentation, pityriasis alba, senile leukodermachemical/drug-induced leukoderma

\begin{tabular}{|c|c|c|c|}
\hline \multicolumn{4}{|c|}{ Hypopigmentation related with systemic disorders and others } \\
\hline Ataxia telangiectasia & $\begin{array}{l}\text { Cancer predisposition and } \\
\text { neurodegenerative disorders }\end{array}$ & ATM & $\begin{array}{l}\text { Ataxia-telangiectasia mutated, } \\
\text { DNA-damage response, signal } \\
\text { transduction, and cell-cycle } \\
\text { control }\end{array}$ \\
\hline Tietz syndrome & $\begin{array}{l}\text { Congenital profound deafness } \\
\text { and generalized } \\
\text { hypopigmentation }\end{array}$ & MITF & $\begin{array}{l}\text { Transcription factor; master } \\
\text { regulator of melanocyte lineage }\end{array}$ \\
\hline Tuberous sclerosis & $\begin{array}{l}\text { Seizures, mental retardation, and } \\
\text { cutaneous angiofibromas/ } \\
\text { development of multiple } \\
\text { hamartomas/ash leaf macule }\end{array}$ & mTOR & Tuberin and hamartin \\
\hline Werner synderome & $\begin{array}{l}\text { Adult onset segmental progeroid } \\
\text { syndrome }\end{array}$ & WRN & $\begin{array}{l}\text { Werner syndrome, RecQ helicase- } \\
\text { like }\end{array}$ \\
\hline
\end{tabular}

Others

Alezzandrini syndrome, Preus syndrome, Tothmund-Thomson syndrome, infectious diseases

Mixed hyper-/hypopigmentation disorder

Congenital

Incontinentia

pigmenti

Dyschromatosis symmetrica hereditaria

Xeroderma pigmentosum type A

Xeroderma pigmentosum type B

Xeroderma pigmentosum type $\mathrm{C}$

Xeroderma pigmentosum type D

$\begin{array}{ccc}\begin{array}{c}\text { Four stages: vesicles, verrucous } \\ \text { lesions, hyperpigmentation, } \\ \text { and hypopigmentation }\end{array} & \begin{array}{c}\text { NEMO/ } \\ \text { IKBKG }\end{array} & \begin{array}{c}\text { Nuclear factor- } \kappa \mathrm{B} \text { essential } \\ \text { modulator/inhibitor of } \kappa \text { light } \\ \text { polypeptide gene enhancer in B }\end{array} \\ \begin{array}{c}\text { Mixture of hyperpigmented and } \\ \text { cells, kinase } \gamma\end{array} & \text { ADAR } 1 & \begin{array}{c}\text { Double-stranded RNA-specific } \\ \text { adenosine deaminase }\end{array}\end{array}$
distributed on the face and the dorsal aspects of the extremities

UV-induced carcinogenesis

XPA

Xeroderma pigmentosum type A

ERCC3

XPC

Excision repair crosscomplementation group 3; nucleotide excision repair (NER)

Xeroderma pigmentosum type $\mathrm{C}$

ERCC2

Excision repair crosscomplementation group 2; nucleotide excision repair (NER) 
Melanocytes and Their Diseases

Table 1. Continued

\begin{tabular}{|c|c|c|c|}
\hline $\begin{array}{l}\text { Representative } \\
\text { disease }\end{array}$ & Disease brief description & Locus & Mechanism(s) of action \\
\hline $\begin{array}{l}\text { Xeroderma } \\
\text { pigmentosum } \\
\text { type E }\end{array}$ & & DDB2 & $\begin{array}{l}\text { Double-stranded DNA-binding } \\
\text { protein } 2\end{array}$ \\
\hline $\begin{array}{l}\text { Xeroderma } \\
\text { pigmentosum } \\
\text { type F }\end{array}$ & & ERCC4 & $\begin{array}{l}\text { Excision repair cross- } \\
\text { complementation group } 4 \text {; } \\
\text { nucleotide excision repair (NER) }\end{array}$ \\
\hline $\begin{array}{l}\text { Xeroderma } \\
\text { pigmentosum } \\
\text { type } G\end{array}$ & & ERCC5 & $\begin{array}{l}\text { Excision repair cross- } \\
\text { complementation group } 5 \text {; } \\
\text { nucleotide excision repair (NER) }\end{array}$ \\
\hline $\begin{array}{l}\text { Xeroderma } \\
\text { pigmentosum } \\
\text { type } \mathrm{V}\end{array}$ & & POLH & $\begin{array}{l}\text { Polymerase (DNA directed), } \eta \\
\quad(\text { RAD } 30 \text { related) }\end{array}$ \\
\hline Acquired & & & \\
\hline $\begin{array}{l}\text { Photoleuko- } \\
\text { melanoderma, } \\
\text { drug-induced } \\
\text { disorders }\end{array}$ & & & \\
\hline
\end{tabular}

modifiers, including $\alpha \mathrm{MSH}$ (Tobin 2011). Additionally, Li et al. (2010) also reported that dermal melanocyte stem cells derived from glabrous human foreskin (i.e., with no hair follicles) can differentiate into functional epidermal melanocytes using a three-dimensional skin equivalent model.

These results make us wonder whether human fetal and/or adult melanocytes are heterogeneous. Human adult melanocytes in skin on the palms and soles may be different from melanocytes derived from other sites of the skin based on the facts that melanocyte migration stops at the palms and soles during embryogenesis and that skin on the palms and soles is hypopigmented and contains a fivefold lower density of melanocytes than at other skin areas. Additionally, fibroblasts in the dermis of the palms and soles secrete high levels of DKK1 (dickkopf1), which is an inhibitor of the Wnt signaling pathway and suppresses the proliferation and differentiation of those melanocytes (Yamaguchi et al. 2004). Preliminary results obtained from human fetal melanocytes cultured from four different body sites (scalp, back, abdomen, and sole) indicate that palmoplantar melanocytes express high levels of DKK1, TBX4, WIF1, FGF7, and CHI3L1 (Nakamura et al. 2012). Although the relevance to melanocytes has not been elucidated, a series of studies from Chang's group showed that the expression patterns of homeotic genes (HOX genes, which are expressed in a nested pattern along developmental axes) determine positional identities within the human body (Chang 2009) and that a long noncoding RNA, which used to be considered to have nonspecific roles, has site-specificity (Rinn et al. 2007) and maintains active chromatin to coordinate HOX gene expression (Wang et al. 2011). Additionally, the expression levels of distal-specific HOXA13 are up-regulated in adult fibroblasts in the skin of paws of mice, thereby inducing the expression of Wnt5A, a morphogen required for distal development, in fibroblasts and of keratin 9, a distal specific marker of epidermis, in keratinocytes (Rinn et al. 2008). These results obtained in studies of mice support the hypothesis that mesenchymal-epithelial interactions play important roles in maintaining the site-specificity of the skin (Yamaguchi et al. 2005).

Taken together, human fetal and adult melanocytes may be heterogeneous/site-specific because those melanocytes are also regulated and maintained by site-specific HOX genes, whose expression patterns are eventually deter- 
mined by chromatins and long noncoding RNAs. That melanocyte heterogeneity may be affected both by intrinsic factors, including a site-specific transcription factor, HOX, and by extrinsic factors secreted by surrounding resident cell types: fibroblasts and keratinocytes. The fact that acral melanoma is different from other types of melanoma (Curtin et al. 2005), especially in that AMP kinase-related NUAK2 expression levels are high in patients with poor prognosis acral melanoma (Namiki et al. 2011), may also support the idea that melanocytes are heterogeneous.

\section{MELANOCYTE STEM CELLS}

As recently summarized by Nishimura (2011), research on melanocyte stem cells (MelSCs) is also in the spotlight. A series of studies by her group showed that MelSCs are immature melanoblasts expressing high levels of dopachrome tautomerase (DCT) and low levels of Kit located in the lower permanent portion of the hair follicle (Nishimura et al. 2002). MelSCs directly adhere to hair follicle stem cells whose high expression levels of collagen XVII (COL17A1, BP180, or BPAG2) play important roles in maintaining MelSCs, which do not express COL17A1 (Tanimura et al. 2011). MelSCs surely serve as a melanocyte reservoir for the pigmentation of both the hair and the skin based on the fact that repigmentation usually occurs at the orifices of hair follicles in the skin of vitiligo patients. Future studies may elucidate the mechanism(s) by which MelSCs are maintained and regulated in skin at the palms and soles, where hair follicles do not physiologically exist.

\section{MELANOCYTE SENESCENCE}

The aging process in human skin eventually results not only in brittle/thin/inelastic skin and senile lentigines/lentigo but also hair graying and senile leukoderma. As for hair graying, Nishimura et al. (2005) reported that a Bcl2 deficiency accelerates the selective apoptosis of MelSCs, thereby disturbing the self-maintenance of MelSCs, resulting in hair graying. They also reported that mutations in MITF ac- celerate ectopic pigmentation or differentiation within the niche, thereby causing the physiological aging of MelSCs (Nishimura et al. 2005). Genotoxic stress also results in the depletion of MelSCs and in the irreversible hair graying caused by their unscheduled differentiation (Inomata et al. 2009). Other factors involved in hair graying include defective TGF- $\beta$ signaling from hair follicle stem cells and abnormal regulation of the Notch and Wnt signaling pathways (Nishimura 2011). Similar mechanisms may be involved in the pathogenesis of senile leukoderma, although this disease concept is not yet well accepted worldwide.

Ectopic up-regulation of MelSC function caused by aging and/or UV-irradiation may be involved in the formation of senile lentigines/ lentigo and other age-related hyperpigmentation disorders. Cosmetic companies usually focus on developing antiaging products, but the senescence process is beneficial in preventing tumorigenesis. Generally speaking, senescent cells are defined as cells with permanent proliferative arrest irrespective of physiological mitogenic stimuli, expressing $\beta$-galactosidase and senescence-associated heterochromatic foci. Factors that initiate and maintain the senescence program include BRAF, NRAS, p16INK4a, p21Waf1, p53, and pRb (Haferkamp and Rizos 2010). Benign nevi typically remain growth arrested and contain abundant numbers of senescent cells, although senescent cells are absent in advanced melanomas and in normal melanocytes. The expression of BRAFV600E in melanocytes increases the synthesis and secretion of IGFBP7, which may be required for melanocyte senescence, based on multidisciplinary studies, including the use of shRNA specific for IGFBP7 (Wajapeyee et al. 2010).

Future studies regarding melanocyte senescence will contribute to both tissue regeneration (hair graying and antiaging) and melanoma treatment.

\section{FACTORS THAT REGULATE MELANIN PRODUCTION WITHIN MELANOCYTES}

Pigment-specific factors that modulate melanin production within melanocytes are usually 


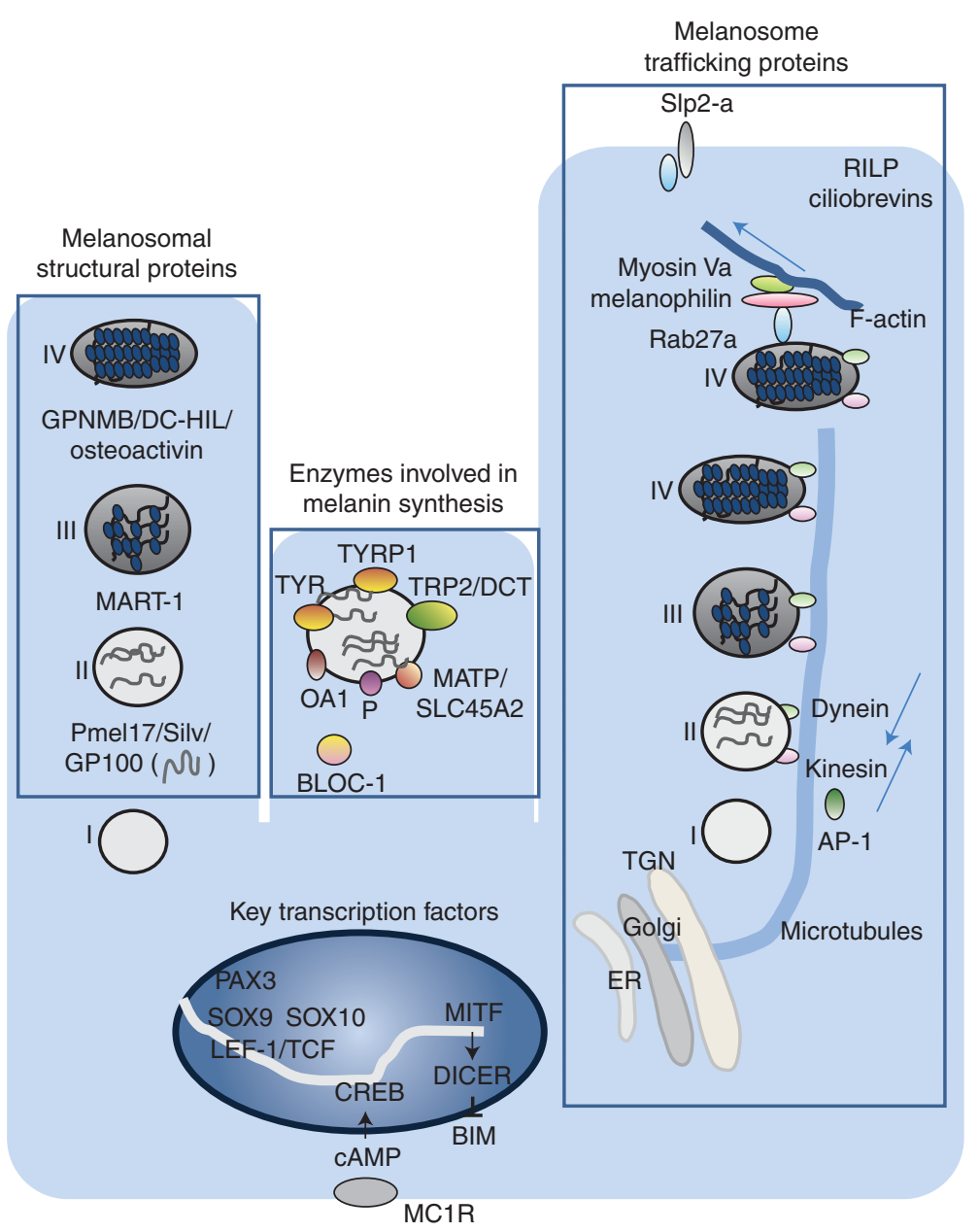

Figure 1. Factors that regulate melanin production within melanocytes. Critical factors consist of proteins that affect melanosome structure (Pmel17, MART-1, and GPNMB), proteins that modulate melanin synthesis either directly or indirectly (TYR, TYRP1, DCT, BLOC-1, OA1, P, and SLC45A2), proteins involved in the trafficking of melanosome proteins or the intracellular transport of melanosomes (microtubules, F-actin, kinesin, dynein, Rab27a, melanophilin, myosin Va, RILP, ciliobrevins, and Slp2-a), and melanocyte-specific transcription factors (PAX3, SOX9/10, LEF-1, CREB, DICER, and MITF). Melanosomes mature through distinct stages, noted as I, II, III, and IV in this diagram.

located within, on, or close to melanosomes and can be divided into three types (Fig. 1): proteins involved in melanosome structure, proteins that regulate melanin synthesis, and proteins involved in the intracellular trafficking of melanosome components and the transport of melanosomes to the cell's periphery (Yamaguchi and Hearing 2009). Transcription factors specifically expressed by melanocytes and by melanoma cells (especially MITF) regulate the expres- sion and function of many of those pigmentspecific factors. We briefly update several important findings since our review published several years ago (Yamaguchi and Hearing 2009).

\section{Melanosomal Structural Proteins}

Three important structural proteins that form melanosomes include PMEL17/Silv/GP100, MART-1 (melanoma antigen recognized by 
T cell-1), and GPNMB (glycoprotein non-metastatic melanoma protein b)/DC-HIL/osteoactivin. PMEL17 forms an amyloidogenic fibril depending on the critical acidic $\mathrm{pH}(5.0 \pm 0.5)$ within melanosomes (Pfefferkorn et al. 2010). Studying PMEL17 mutations can be useful to investigate the conversion between physiological/benign and pathological amyloid proteins (Watt et al. 2011). MART-1, which is abundant in early melanosomes, is required for the maturation of PMEL17 (Hoashi et al. 2005). GPNMB, which is highly homologous to Pmel17 but lacks the RPT domain (imperfect repeats of proline, serine, and threonine-rich motifs), is a melanosome-specific and proteolytically released protein, which is abundant in late melanosomes (Hoashi et al. 2010). GPNMB is critical for the formation of melanosomes in a MITF-independent fashion (Zhang et al. 2012). These structural melanosomal proteins provide scaffold materials to the enzymes required for melanin deposition and on which the melanins are deposited.

\section{Enzymes Involved in Melanin Synthesis}

There are three key enzymes that play critical roles in melanin synthesis within melanosomes: TYR (tyrosinase), TYRP1 (tyrosinase related protein-1), and TRP2/DCT (dopachrome tautomerase). Many factors, including BLOC-1, OA1, P, and SLC45A2 (previously known as MATP) influence the trafficking and thus the function of these enzymes. Of note, metal ions including zinc and copper serve as catalysts and/or chelators when melanin is synthesized (Simon et al. 2009) and metal remnants in fossils enable us to predict the colors of dinosaurs (Wogelius et al. 2011), in addition to determining the configurations of melanosomes ( $\mathrm{Li}$ et al. 2012). Cystinosin, a cysteine $/ \mathrm{H}^{+}$symporter that exports cysteine out of lysosomes, is the gene associated with cystinosis, a rare autosomal recessive disorder with multiple organ dysfunctions including hypopigmentation (Chiaverini et al. 2012). Additionally, $\mathrm{NAD}(\mathrm{P}) \mathrm{H}$ :quinone oxidoreductase- 1 enhances melanogenesis by increasing the levels of TYR protein (Choi et al. 2010). The regulation of intramelanosomal
$\mathrm{pH}$ may play important roles for regulating the appropriate enzymatic functions in melanin synthesis as well as the processing and function of melanosomal structural proteins.

\section{Melanosome Trafficking Proteins}

Melanin granules are transported from the perinuclear area to the periphery of melanocytes and are eventually transferred to adjacent keratinocytes (Yamaguchi and Hearing 2009). Early melanosomes, produced via the trans-Golgi network and/or endocytosis, originate in the perinuclear area and then mature to late (pigmented) melanosomes as they move toward the periphery of the melanocyte (i.e., the dendrites). In this trafficking pathway, kinesin ( prograde) and dynein (retrograde) act like wheels for melanosomal cargo and microtubules function like rails. The clathrin adaptor AP-1 is reported to interact with the kinesin motor KIF13A, suggesting the role of adaptor proteins in melanosome trafficking (Delevoye et al. 2009). The melanosomal cargo is transferred from microtubules to F-actin, which acts as a rail, at the periphery of the melanocyte. Semiautomated analysis of organelle movement and membrane content reveals the involvement of Rab27a and its complex in the regulation of this transfer (Hume et al. 2011). Rab27a, melanophilin, and myosin Va are connected to melanosomes in that order and function like wheels. Finally, Slp2-a may regulate melanosomal cargo exocytosis. Recent findings show that melanoregulin regulates retrograde melanosome transport via the interaction with RILP (Rab-interacting lysosomal protein) and its complex (dynactin subunit 1) (Ohbayashi et al. 2012). Ciliobrevins were discovered as small-molecule inhibitors of the $\mathrm{AAA}^{+}$(ATPases associated with diverse cellular activities) ATPase dynein (Firestone et al. 2012). Studies further elucidating melanosome trafficking might be enhanced in the near future characterizing these factors.

\section{Melanocyte-Specific Transcription Factors}

MITF has been investigated intensively among the many transcription factors known to reg- 
ulate melanocyte function. MITF itself is regulated by many other transcription factors, including PAX3 (a neural-crest-associated transcription factor), SOX9, SOX10, LEF-1/TCF (a downstream regulator of Wnt signaling pathway), and CREB (cAMP responsive-elementbinding protein, which is phosphorylated by signals via MC1R, melanocortin-1 receptor) (Yamaguchi and Hearing 2009).

Fisher's group recently reported that MITF directly up-regulates DICER, an endoribonuclease in the RNase III family that cleaves double-stranded RNA and pre-microRNA into short RNA fragments (20-25 nucleotides long), on melanocyte differentiation (Levy et al. 2010). Enhanced DICER expression plays a crucial role in melanocyte survival via the posttranscriptional processing of the pre-microRNA-17 92 cluster, which leads to the down-regulation of BIM, a proapoptotic factor.

\section{PIGMENTARY DISORDERS}

As summarized above, the regulation of pigmentation involves many factors required for development, heterogeneity, regeneration, and senescence of melanocytes and their precursors, as well as those involved in determining melanosome structure, melanin synthesis, the trafficking of melanosomal components and the transport and distribution of melanosomes, and melanocyte-specific transcription factors that control the expression and function of all those genes. More than 350 loci are currently known to be directly or indirectly involved with those processes in mice and mutations of many of those genes have been associated with human pigmentary disorders. Those include hyperpigmentation, hypopigmentation, and mixed hyper-/ hypopigmentation disorders and can be diagnosed by size (systemic or localized), comorbidities, site of the involvement, and patterns/ shapes of the lesions (Table 1). Those are subclassified into congenital and acquired disorders and in addition hypopigmentation disorders can also be subclassified into complete and incomplete depigmentation. Among the many pigmentary disorders summarized in Table 1, we focus on vitiligo because of space limitations.

\section{Congenital Hyperpigmentation Disorders}

Congenital hyperpigmentation disorders include those involving epidermal hyperpigmentation (nevus cell nevus, Spitz nevus, and nevus spilus), dermal hyperpigmentation (blue nevus, nevus Ohta, dermal melanosis, nevus Ito, and Mongolian spot), ephelides, acropigmentatio reticularis, Spitzenpigment/acropigmentation, and lentiginosis (generalized lentiginosis, LEOPARD syndrome, inherited patterned lentiginosis, Carney complex, Peutz-Jeghers syndrome, Laugier-Hunziker-Baran syndrome, and Cronkhite-Canada syndrome).

The responsible locus for generalized lentiginosis, characterized by widespread lentigines without systemic involvement, has been localized to chromosome 4q21.1-q22.3 (Xing et al. 2005). LEOPARD syndrome is characterized by multiple lentigines, congenital cardiac abnormalities, ocular hypertelorism, and retardation of growth, and many reports have shown its association with mutations in the PTPN11 (protein tyrosine phosphatase, nonreceptor type 11) gene located at chromosome 12q24 since Legius et al. (2002) first reported the association with Noonan syndrome. Carney complex, a multiple neoplasia syndrome characterized by spotty skin pigmentation, cardiac and other myxomas, endocrine tumors, and psammomatous melanotic schwannomas, has been shown to be caused by mutations in PRKAR1A ( protein kinase A regulatory subunit $1 \alpha$ ), a tumor-suppressor gene (Kirschner et al. 2000). Peutz-Jeghers syndrome, which predisposes to benign and malignant tumors of many organ systems, has been reported to be associated with mutations in STK11 (serine/threonine protein kinase)/LKB1 (Hemminki et al. 1998).

\section{Acquired Hyperpigmentation Disorders}

Acquired hyperpigmentation disorders include senile lentigines/lentigo, melasma/chloasma, Riehl's melanosis, labial melanotic macule, penile/vulvovaginal melanosis, erythromelanosis follicularis faciei Kitamura, UV-induced pigmentation (tanning and pigmentation petal- 
oides actinica), postinflammatory pigmentation (friction melanosis and ashy dermatosis), chemical/drug-induced pigmentation (polychlorinated biphenyl, arsenic, 5-FU, bleomycin, cyclophosphamide, methotrexate, chlorpromazine, phenytoin, tetracycline, and chloroquine), pigmentary demarcation lines, foreign material deposition (such as carotene, silver, gold, mercury, bismuth, and tattoos). Hyperpigmentation related with systemic disorders includes metabolism/enzyme disorders (hemochromatosis, Wilson's disease, Gaucher's disease, Niemann-Pick's disease, amyloidosis, ochronosis, acanthosis nigricans, and porphyria cutanea tarda), endocrine disorders (Addison's disease, Cushing syndrome, and hyperthyroidism), nutritional disorders ( pellagra, vitamin B12 deficiency, folic acid deficiency, vagabond's disease, and prurigo pigmentosa), mastocytosis, collagen diseases, liver dysfunction, and kidney dysfunction. Hyperpigmentation can also be related with infectious diseases (measles, syphilis, and Malassezia furfur) and syndromes (von Recklinghausen's disease, Sotos syndrome, POEMS syndrome, Naegeli syndrome, Cantu syndrome, McCune-Albright syndrome, Watson syndrome, and Bloom syndrome).

Bioinformatics studies have shown that genes responsible for melasma include Wnt and lipid metabolism-related genes in addition to melanogenic markers (Kang et al. 2011) and that reduced expression levels of WIF-1 (Wnt inhibitory factor-1) in keratinocytes and/or fibroblasts may play roles in the development of melasma (Kim et al. 2013). Patients with mastocytosis usually carry the D816 V KIT mutation and a bioinformatics study shows that those patients show the up-regulation of genes involved in innate and inflammatory immune responses, including interferon-induced genes and genes involved in cellular responses to viral antigens, together with complement inhibitory molecules and genes involved in lipid metabolism and protein processing. Aggressive mastocytosis additionally shows deregulation of apoptosis and cell cycle-related genes, whereas patients with indolent mastocytosis display increased expression levels of adhesion-related molecules (Teodosio et al. 2013). Sotos syn- drome, characterized by childhood overgrowth with advanced bone age, craniofacial dysmorphic features including macrocephaly and learning difficulties, results from the haploinsufficiency of NSD1 (nuclear receptor binding SET domain protein 1) (Kurotaki et al. 2002). POEMS syndrome (polyneuropathy, organomegaly, endocrinopathy, M-protein, and skin changes) is a multisystem disorder associated with plasma cell dyscrasia, and patients with POEMS syndrome show up-regulated serum levels of angiogenetic factors including VEGF (vascular endothelial growth factor) and HGF (hepatocyte growth factor) (Yamada et al. 2013). Cantu syndrome, characterized by hypertrichosis, macrosomia, osteochondrodysplasia, and cardiomegaly, is reported to be caused by mutations in ABCC9 (ATP-binding cassette, subfamily C, member 9) (van Bon et al. 2012). McCune-Albright syndrome results from somatic mutations of the GNAS gene (G-protein $\alpha$-subunit) especially mutations in Gs $\alpha$ (stimulatory $\mathrm{G}$ protein) (Dumitrescu and Collins 2008). The causative gene for Bloom syndrome, with photosensitivity and increased risk of malignancy, is BLM (Bloom syndrome, RecQ helicase-like), localized at chromosome 15q26.1 (German et al. 1994).

\section{Congenital Hypopigmentation Disorders}

Congenital hypopigmentation disorders include various types of oculocutaneous albinism (OCA1-4, Hermansky-Pudlak syndrome, Chediak-Higashi syndrome, and Griscelli syndrome), Cross-McKusick-Breen syndrome, phenylketonuria, piebaldism, Waardenburg syndrome, nevus depigmentosus, hypomelanosis of Ito, Hirschprung's disease, Charcot-MarieTooth disease, Menkes disease, and Wilson disease.

Many of the genes responsible for those hypopigmentary disorders have been identified and in general are involved with the intracellular trafficking of proteins to LROs (including melanosomes), in the transport of organelles to the peripheries of the cell and in their transfer to surrounding keratinocytes. Figure 2 outlines the diagnostic decision tree for representative 
Congenital hypopigmentation disorders

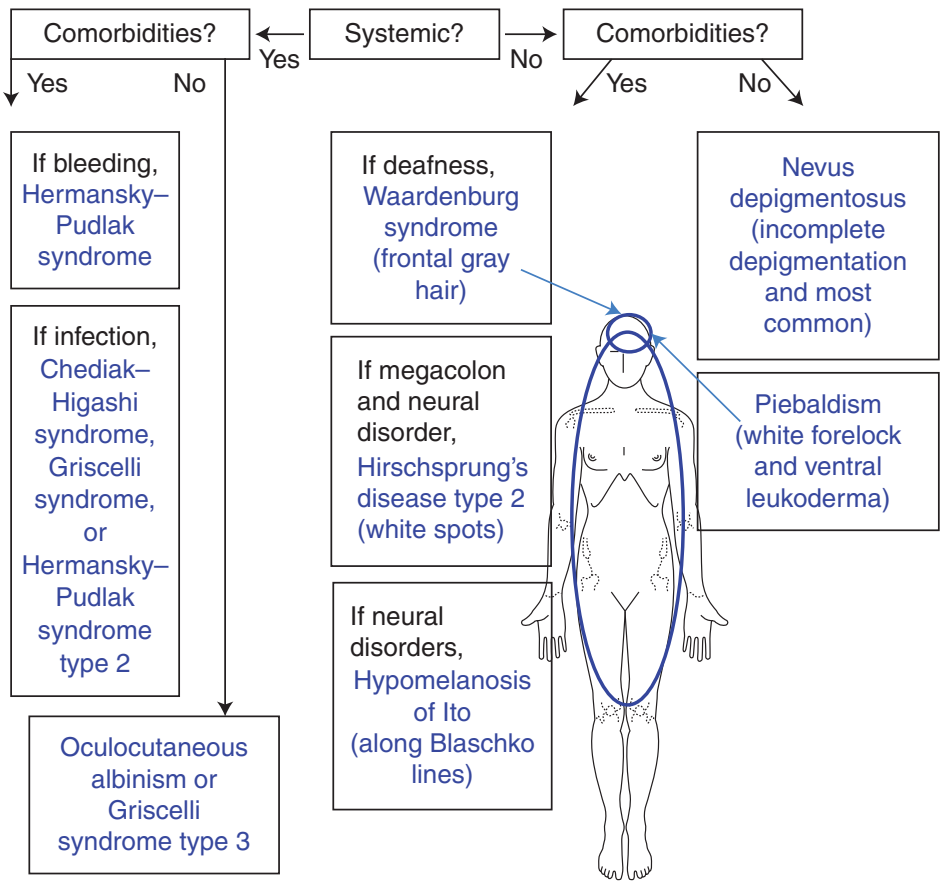

Figure 2. Diagnosis of congenital hypopigmentation disorders. Key elements for accurate diagnosis are size (systemic or localized), comorbidities, site of the involvement, and patterns/shapes of the lesions.

congenital hypopigmentation disorders, and we recommend that interested readers check the many references shown in the ESPCR webpage for further details and updates of genes associated with congenital hypopigmentary diseases. As recently reviewed, Hermansky-Pudlak syndrome, characterized by oculocutaneous albinism, prolonged bleeding times, and pulmonary fibrosis, is triggered by syndromic dysgenesis of specialized LROs including melanosomes, platelet granules, synaptic vesicles, lytic granules, Azurophil granules, and lamellar bodies (Wei and Li 2013). Its responsible dysfunctional proteins include the biogenesis of lysosome-related organelles complex 1 (BLOC-1), BLOC-2, BLOC-3, and AP-3. For example, the responsible gene for Hermansky-Pudlak syndrome type 7 is DTNBP1 (dysbindin), a component of BLOC-1 (Li et al. 2003). Hypomelanosis of Ito may be derived from duplication of Xp11.3-p11.4 and random X-inactivation (Zou and Milunsky 2009).

\section{Acquired Hypopigmentation Disorders}

Acquired hypopigmentation disorders include vitiligo, Sutton nevus, Vogt-KoyanagiHarada disease, malignancy-induced hypopigmentation (from melanoma and mycosis fungoides), postinflammatory hypopigmentation, chemical/drug-induced leukoderma, senile leukoderma, and pityriasis alba. Most of these acquired hypopigmentation disorders are associated with inflammation and a recent study shows that TNF- $\alpha$ and IL-17 synergistically suppress pigmentation-related signaling and melanin production partly via MC1R (Wang et al. 2013). Hypopigmentation is also related with other syndromes (such as ataxia telangiectasia, Alezzandrini syndrome, Preus syndrome, Tietz syndrome, tuberous sclerosis, Rothmund-Thomson syndrome, and Werner syndrome) and infections (such as HIV, Hansen's disease, Malassezia furfur, and syphilis). Vitiligo is discussed further below. 
Vogt-Koyanagi-Harada disease is a bilateral, chronic, diffuse granulomatous uveitis with poliosis, vitiligo, central nervous system, and auditory signs. Many researchers, especially Yang's group, have investigated the gene polymorphisms of many factors including IL-17 that are associated with Vogt-Koyanagi-Harada disease in a Chinese Han population (Shu et al. 2010) since Yakura et al. first reported the HLA-D locus linkage (Yakura et al. 1976). The causative gene for ataxia telangiectasia is ATM (ataxia-telangiectasia mutated) localized at 11q22.3-23 (Ambrose and Gatti 2013). Amiel et al. reported that mutations in MITF result in Tietz syndrome (albinism-deafness) similar to Waardenberg syndrome type 2 (Amiel et al. 1998). Tuberous sclerosis results from dysregulation of mTOR signaling caused by mutations in tuberin and/or hamartin and Wataya-Kaneda et al. reported that angiofibromas can be treated with topical rapamycin ointment (Wataya-Kaneda et al. 2011). Although Werner syndrome is generally caused by mutations in the WRN gene, a recent epigenetic study shows that aberrant DNA methylation profiles result in premature aging diseases (Heyn et al. 2013).

\section{Mixed Hyper-/Hypopigmentation Disorders}

Congenital mixed hyper-/hypopigmentation disorders include incontinentia pigmenti, dyschromatosis symmetrica hereditaria (DSH), and xeroderma pigmentosum (XP), and acquired hyper-/hypopigmentation disorders include photoleukomelanoderma and drug-induced mixed hyper-/hypopigmentation.

Incontinentia pigmenti, a rare $\mathrm{X}$-linked genodermatosis, commonly consists of 4 stages: inflammatory vesicular rash, verrucous lesions, linear or reticular hyperpigmentation, and finally atrophic hypopigmented skin. Many investigators have reported that gene mutations responsible for incontinentia pigmenti occur in NEMO (nuclear factor- $\kappa \mathrm{B}$ essential modulator)/IKBKG (inhibitor of $\kappa$ light polypeptide gene enhancer in B cells, kinase $\gamma$ ), located at chromosome Xq28 (Fusco et al. 2012).
DSH, also called reticulate acropigmentation of Dohi, is a pigmentary genodermatosis of autosomal dominant inheritance and two groups have reported that the causative gene is ADAR1 (DSRAD; double-stranded RNA-specific adenosine deaminase) (Li et al. 2005; Suzuki et al. 2005). Various types of XP are reviewed elsewhere (DiGiovanna and Kraemer 2012), but mutations of DNA repair related genes after UV-induced damage play key roles in the formation of XP.

\section{Vitiligo as a Representative of an Acquired Hypopigmented Disorder}

Simple physical examination (lesions are depigmented completely at the initiation phase, pigmented orifices of hair follicles are seen at the recovering phase, and hyperpigmented ridges surrounded by the lesion are seen at the stable/intractable phase) and/or present history (acquired depigmentation with or without autoimmune comorbidities) should be sensitive and specific enough for the correct diagnosis of vitiligo (Taieb and Picardo 2009), and which can sometimes be confused with other hypopigmented disorders (listed in Table 1 and see above). However, it may be difficult to differentiate vitiligo from nevus depigmentosus at childhood because depigmentation is not usually remarkable at infancy. Vitiligo can be divided into two categories: generalized vitiligo (wide distribution) and segmental vitiligo (confined to the dermatome). Typically, generalized vitiligo starts from the face and/or the dorsal side of the hands, which are cosmetically important part(s) of the body, and occurs mostly during adolescence/puberty. Comorbidities include other autoimmune diseases including thyroid disease and pernicious anemia. The prevalence is approximately $0.5 \%$ with different studies estimating a prevalence rate of $0.2 \%-0.9 \%$ (Nordlund 1997) and vitiligo is the 18th commonest disease seen in Japanese dermatology clinics (Furue et al. 2011). The course of the disease appears to be unpredictable; the skin lesions are often stable for more than a year whereas others are slowly/rapidly progressive. The spontaneous healing rate is ap- 
proximately $10 \%$. The impact of vitiligo on the patients' quality of life may be higher in more pigmented populations and in young adults based on the contrast of depigmented lesions and their surrounding areas and the social activities, respectively. In general, socially active patients tend to be eager to undergo any possible treatment options aiming for a cure, and socially inactive patients are often untreated or undertreated.

As summarized by Grimes (2005), the presence of $\mathrm{CD}^{+} \mathrm{T}$ cells in close apposition to melanocytes suggests that the pathogenesis of vitiligo is $\mathrm{T}$ cell mediated. The disease may also be antibody mediated in that vitiligo patients frequently have antibodies to surface and cytoplasmic melanocyte antigens. Increased cytokine levels, including IFN- $\gamma$ and TNF- $\alpha$, have been detected in the skin of vitiligo patients. Tacrolimus-induced repigmentation of vitiligo lesions is related with a reduction to normal of the elevated TNF- $\alpha$ in the lesional skin.

Many candidate genes/loci are thought to be involved with the pathogenesis of vitiligo. Among them, Spritz's group recently reported significant associations between generalized vitiligo (from European-derived white ancestry) and SNPs (single-nucleotide polymorphisms) at many responsible loci using genome-wide association analyses. Most, if not all, of those genes are involved with regulation/function of the immune system. In addition to the NALP1 gene (Jin et al. 2007), those include MHCI, MHCII, PTPN22, LPP, IL2RA, UBASH3A, C1QTNF6, RERE, GZMB (Jin et al. 2010a), FOXP1, CCR6 (Jin et al. 2010b), OCA2-HERC2, MC1R, a region near TYR, IFIH1, CD80, CLNK, BACH2, SLA, CASP7, CD44, IKZF4, SH2B3, and TOB2 (Jin et al. 2012). The same group also reported the involvement of NLRP1, a key regulator of the innate immune system, in the pathogenesis of vitiligo (Levandowski et al. 2013). Although there is currently no single complete cure available to treat vitiligo (Oiso et al. 2013), these series of studies may bring new approaches for therapy to vitiligo patients in the near future after careful clinical trials.

\section{MELANOMA-THE MALIGNANT MELANOCYTE}

It is beyond the scope of this review to cover the topic of melanoma, the transformed melanocyte, other than to say that it is the most lethal of all types of skin cancers and its incidence is growing at an alarming rate. A number of gene loci have been characterized that are associated with the process of malignant transformation, growth, and metastasis of melanoma cells, and these have been recently reviewed by Fisher's group (Tsao et al. 2012). Several melanoma susceptibility genes are related with genes responsible for pigmentation disorders including XP and LEOPARD syndrome. We refer readers to Hawryluk and Tsao (2014) for further information about melanoma. Of note, the gene expression profile of acral melanoma is dramatically different from the profiles of other types of melanoma (Curtin et al. 2005). Because the origin of melanocytes may be diverse depending on the site, UV-induced, non-UV-induced, acral, and mucosal melanomas may need to be treated with different therapeutic regimens. Preliminary data show that acral melanocytes appear at rete ridges during embryogenesis, which may be related with the dermoscopic patterns of the parallel ridge (instead of furrow) in acral melanoma (data not shown).

\section{CONCLUDING REMARKS}

Here we summarized recent discoveries of melanocyte biology from the aspects of basic and clinical science although space considerations do not allow us to provide a comprehensive overview of all of the important molecules involved in melanogenesis. We recommend that interested readers check the curated pigment gene database of the ESPCR web page because new pigment-related genes are being identified over time. That web site currently lists more than 350 genes associated with pigmentation and is frequently updated and categorized according to the mechanisms of action of those genes and associated pigmentary diseases. Future studies of melanocytes will further elucidate the mechanisms involved in the regulation 
of melanocyte development and heterogeneity, by which hair graying and melanocyte senescence occur, and disruptions of which cause most pigmentary disorders. It is our hope that further studies will lead to the development of complete effective therapies for those disorders, especially malignant melanoma.

\section{ACKNOWLEDGMENTS}

This research was supported by the Intramural Research Program of the National Cancer Institute at NIH. Y.Y. is an AbbVie employee and may receive AbbVie stock, stock options, and grants.

\section{REFERENCES}

${ }^{*}$ Reference is also in this collection.

Adameyko I, Lallemend F, Aquino JB, Pereira JA, Topilko P, Muller T, Fritz N, Beljajeva A, Mochii M, Liste I, et al. 2009. Schwann cell precursors from nerve innervation are a cellular origin of melanocytes in skin. Cell 139: 366379.

Ambrose M, Gatti RA. 2013. Pathogenesis of ataxia-telangiectasia: The next generation of ATM functions. Blood 121: 4036-4045.

Amiel J, Watkin PM, Tassabehji M, Read AP, Winter RM. 1998. Mutation of the MITF gene in albinism-deafness syndrome (Tietz syndrome). Clin Dysmorphol 7: 17-20.

Aoki H, Yamada Y, Hara A, Kunisada T. 2009. Two distinct types of mouse melanocyte: Differential signaling requirement for the maintenance of non-cutaneous and dermal versus epidermal melanocytes. Development 136: $2511-2521$.

Aoki H, Hara A, Motohashi T, Osawa M, Kunisada T. 2011 Functionally distinct melanocyte populations revealed by reconstitution of hair follicles in mice. Pigment Cell Melanoma Res 24: 125-135.

Chang HY. 2009. Anatomic demarcation of cells: Genes to patterns. Science 326: 1206-1207.

Chiaverini C, Sillard L, Flori E, Ito S, Briganti S, Wakamatsu K, Fontas E, Berard E, Cailliez M, Cochat P, et al. 2012. Cystinosin is a melanosomal protein that regulates melanin synthesis. FASEB J 26: 3779-3789.

Choi TY, Sohn KC, Kim JH, Kim SM, Kim CH, Hwang JS Lee JH, Kim CD, Yoon TJ. 2010. Impact of NAD(P)H: quinone oxidoreductase-1 on pigmentation. J Invest Dermatol 130: 784-792.

Curtin JA, Fridlyand J, Kageshita T, Patel HN, Busam KJ Kutzner H, Cho KH, Aiba S, Brocker EB, LeBoit PE, et al. 2005. Distinct sets of genetic alterations in melanoma. N Engl J Med 353: 2135-2147.

Delevoye C, Hurbain I, Tenza D, Sibarita JB, Uzan-Gafsou S, Ohno H, Geerts WJ, Verkleij AJ, Salamero J, Marks MS, et al. 2009. AP-1 and KIF13A coordinate endosomal sorting and positioning during melanosome biogenesis. J Cell Biol 187: 247-264.

DiGiovanna JJ, Kraemer KH. 2012. Shining a light on xeroderma pigmentosum. J Invest Dermatol 132: 785-796.

Dumitrescu CE, Collins MT. 2008. McCune-Albright syndrome. Orphanet J Rare Dis 3: 12.

Firestone AJ, Weinger JS, Maldonado M, Barlan K, Langston LD, O’Donnell M, Gelfand VI, Kapoor TM, Chen JK. 2012. Small-molecule inhibitors of the $\mathrm{AAA}^{+}$ATPase motor cytoplasmic dynein. Nature 484: 125-129.

Furue M, Yamazaki S, Jimbow K, Tsuchida T, Amagai M, Tanaka T, Matsunaga K, Muto M, Morita E, Akiyama M, et al. 2011. Prevalence of dermatological disorders in Japan: A nationwide, cross-sectional, seasonal, multicenter, hospital-based study. J Dermatol 38: 310-320.

Fusco F, Pescatore A, Steffann J, Royer G, Bonnefont JP, Ursini MV. 2012. Clinical utility gene card for: Incontinentia pigmenti. Eur J Hum Genet doi: 10.10381. ejhg.2012.227.

German J, Roe AM, Leppert MF, Ellis NA. 1994. Bloom syndrome: An analysis of consanguineous families assigns the locus mutated to chromosome band 15q26.1. Proc Natl Acad Sci 91: 6669-6673.

Grimes PE. 2005. New insights and new therapies in vitiligo. JAMA 293: 730-735.

Haferkamp S, Rizos H. 2010. Oncogene-induced senescence pathways in melanocytes. Cell Cycle 9: 4778-4779.

* Hawryluk EB, Tsao H. 2014. Melanoma: Clinical features and genomic insights. Cold Spring Harb Perspect Med doi: $10.1101 /$ cshperspect.a015388.

Hearing VJ. 2011. Determination of melanin synthetic pathways. J Invest Dermatol 131: E8-E11.

Hemminki A, Markie D, Tomlinson I, Avizienyte E, Roth S, Loukola A, Bignell G, Warren W, Aminoff M, Hoglund P, et al. 1998. A serine/threonine kinase gene defective in Peutz-Jeghers syndrome. Nature 391: 184-187.

Heyn H, Moran S, Esteller M. 2013. Aberrant DNA methylation profiles in the premature aging disorders Hutchinson-Gilford Progeria and Werner syndrome. Epigenetics 8: $28-33$.

Hoashi T, Watabe H, Muller J, Yamaguchi Y, Vieira WD, Hearing VJ. 2005. MART-1 is required for the function of the melanosomal matrix protein PMEL17/GP100 and the maturation of melanosomes. J Biol Chem 280: 14006-14016.

Hoashi T, Sato S, Yamaguchi Y, Passeron T, Tamaki K, Hearing VJ. 2010. Glycoprotein nonmetastatic melanoma protein b, a melanocytic cell marker, is a melanosomespecific and proteolytically released protein. FASEB J 24: 1616-1629.

Hume AN, Wilson MS, Ushakov DS, Ferenczi MA, Seabra MC. 2011. Semi-automated analysis of organelle movement and membrane content: Understanding rab-motor complex transport function. Traffic 12: 1686-1701.

Inomata K, Aoto T, Binh NT, Okamoto N, Tanimura S, Wakayama T, Iseki S, Hara E, Masunaga T, Shimizu H, et al. 2009. Genotoxic stress abrogates renewal of melanocyte stem cells by triggering their differentiation. Cell 137: $1088-1099$.

Jin Y, Mailloux CM, Gowan K, Riccardi SL, LaBerge G, Bennett DC, Fain PR, Spritz RA. 2007. NALP1 in vitiligo- 
associated multiple autoimmune disease. $N$ Engl J Med 356: $1216-1225$.

Jin Y, Birlea SA, Fain PR, Gowan K, Riccardi SL, Holland PJ, Mailloux CM, Sufit AJ, Hutton SM, Amadi-Myers A, et al. 2010a. Variant of TYR and autoimmunity susceptibility loci in generalized vitiligo. $N$ Engl J Med 362: $1686-$ 1697.

Jin Y, Birlea SA, Fain PR, Mailloux CM, Riccardi SL, Gowan K, Holland PJ, Bennett DC, Wallace MR, McCormack WT, et al. 2010b. Common variants in FOXP1 are associated with generalized vitiligo. Nat Genet 42: 576-578.

Jin Y, Birlea SA, Fain PR, Ferrara TM, Ben S, Riccardi SL, Cole JB, Gowan K, Holland PJ, Bennett DC, et al. 2012. Genome-wide association analyses identify 13 new susceptibility loci for generalized vitiligo. Nat Genet $\mathbf{4 4}$ 676-680.

Kang HY, Suzuki I, Lee DJ, Ha J, Reiniche P, Aubert J, Deret S, Zugaj D, Voegel JJ, Ortonne JP. 2011. Transcriptional profiling shows altered expression of wnt pathway- and lipid metabolism-related genes as well as melanogenesisrelated genes in melasma. J Invest Dermatol 131: 1692 1700.

Kawakami A, Fisher DE. 2011. Key discoveries in melanocyte development. J Invest Dermatol 131: E2-4.

Kim JY, Lee TR, Lee AY. 2013. Reduced WIF-1 expression stimulates skin hyperpigmentation in patients with melasma. J Invest Dermatol 133: 191-200.

Kirschner LS, Carney JA, Pack SD, Taymans SE, Giatzakis C, Cho YS, Cho-Chung YS, Stratakis CA. 2000. Mutations of the gene encoding the protein kinase A type I $\alpha$ regulatory subunit in patients with the Carney complex. Nat Genet 26: 89-92.

Kondo T, Hearing VJ. 2011. Update on the regulation of mammalian melanocyte function and skin pigmentation. Expert Rev Dermatol 6: 97-108.

Kurotaki N, Imaizumi K, Harada N, Masuno M, Kondoh T, Nagai T, Ohashi H, Naritomi K, Tsukahara M, Makita Y, et al. 2002. Haploinsufficiency of NSD1 causes Sotos syndrome. Nat Genet 30: 365-366.

Legius E, Schrander-Stumpel C, Schollen E, Pulles-Heintzberger C, Gewillig M, Fryns JP. 2002. PTPN11 mutations in LEOPARD syndrome. J Med Genet 39: 571-574.

Levandowski CB, Mailloux CM, Ferrara TM, Gowan K, Ben S, Jin Y, McFann KK, Holland PJ, Fain PR, Dinarello CA, et al. 2013. NLRP1 haplotypes associated with vitiligo and autoimmunity increase interleukin- $1 \beta$ processing via the NLRP1 inflammasome. Proc Natl Acad Sci 110: 2952-2956.

Levy C, Khaled M, Robinson KC, Veguilla RA, Chen PH, Yokoyama S, Makino E, Lu J, Larue L, Beermann F, et al. 2010. Lineage-specific transcriptional regulation of DICER by MITF in melanocytes. Cell 141: 994-1005.

Li W, Zhang Q, Oiso N, Novak EK, Gautam R, O'Brien EP, Tinsley CL, Blake DJ, Spritz RA, Copeland NG, et al. 2003. Hermansky-Pudlak syndrome type 7 (HPS-7) results from mutant dysbindin, a member of the biogenesis of lysosome-related organelles complex 1 (BLOC-1). Nat Genet 35: 84-89.

Li CR, Li M, Ma HJ, Luo D, Yang LJ, Wang DG, Zhu XH, Yue XZ, Chen WQ, Zhu WY. 2005. A new arginine substitution mutation of DSRAD gene in a Chinese family with dyschromatosis symmetrica hereditaria. J Dermatol Sci 37: 95-99.

Li L, Fukunaga-Kalabis M, Yu H, Xu X, Kong J, Lee JT, Herlyn M. 2010. Human dermal stem cells differentiate into functional epidermal melanocytes. J Cell Sci 123: 853-860.

Li Q, Gao KQ, Meng Q, Clarke JA, Shawkey MD, D’Alba L, Pei R, Ellison M, Norell MA, Vinther J. 2012. Reconstruction of Microraptor and the evolution of iridescent plumage. Science 335: 1215-1219.

Nakamura M, Fukunaga-Kalabis M, Yamaguchi Y, Furuhashi T, Nishida E, Kato H, Mizuno T, Sugiura M, Morita A. 2012. Site-specific heterogeneity of melanocytes during late fetal periods. J Invest Dermatol 132: S126.

Namiki T, Tanemura A, Valencia JC, Coelho SG, Passeron T, Kawaguchi M, Vieira WD, Ishikawa M, Nishijima W, Izumo T, et al. 2011. AMP kinase-related kinase NUAK2 affects tumor growth, migration, and clinical outcome of human melanoma. Proc Natl Acad Sci 108: 6597-6602.

Nishimura EK. 2011. Melanocyte stem cells: A melanocyte reservoir in hair follicles for hair and skin pigmentation. Pigment Cell Melanoma Res 24: 401-410.

Nishimura EK, Jordan SA, Oshima H, Yoshida H, Osawa M, Moriyama M, Jackson IJ, Barrandon Y, Miyachi Y, Nishikawa S. 2002. Dominant role of the niche in melanocyte stem-cell fate determination. Nature 416: 854-860.

Nishimura EK, Granter SR, Fisher DE. 2005. Mechanisms of hair graying: Incomplete melanocyte stem cell maintenance in the niche. Science 307: 720-724.

Nordlund JJ. 1997. The epidemiology and genetics of vitiligo. Clin Dermatol 15: 875-878.

Ohbayashi N, Maruta Y, Ishida M, Fukuda M. 2012. Melanoregulin regulates retrograde melanosome transport through interaction with the RILP-p150Glued complex in melanocytes. J Cell Sci 125: 1508-1518.

Oiso N, Suzuki T, Wataya-Kaneda M, Tanemura A, Tanioka M, Fujimoto T, Fukai K, Kawakami T, Tsukamoto K, Yamaguchi Y, et al. 2013. Guidelines for the diagnosis and treatment of vitiligo in Japan. J Dermatol 40: 344354.

Pfefferkorn CM, McGlinchey RP, Lee JC. 2010. Effects of pH on aggregation kinetics of the repeat domain of a functional amyloid, Pmel17. Proc Natl Acad Sci 107: 21447 21452.

Plonka PM, Passeron T, Brenner M, Tobin DJ, Shibahara S, Thomas A, Slominski A, Kadekaro AL, Hershkovitz D, Peters E, et al. 2009. What are melanocytes really doing all day long. . . Exp Dermatol 18: 799-819.

Raposo G, Marks MS. 2007. Melanosomes-dark organelles enlighten endosomal membrane transport. Nat Rev Mol Cell Biol 8: 786-797.

Rinn JL, Kertesz M, Wang JK, Squazzo SL, Xu X, Brugmann SA, Goodnough LH, Helms JA, Farnham PJ, Segal E, et al. 2007. Functional demarcation of active and silent chromatin domains in human HOX loci by noncoding RNAs. Cell 129: 1311-1323.

Rinn JL, Wang JK, Allen N, Brugmann SA, Mikels AJ, Liu H, Ridky TW, Stadler HS, Nusse R, Helms JA, et al. 2008. A dermal HOX transcriptional program regulates site-specific epidermal fate. Genes Dev 22: 303-307. 
Shu Q, Yang P, Hou S, Li F, Chen Y, Du L, Jiang Z. 2010. Interleukin-17 gene polymorphism is associated with Vogt-Koyanagi-Harada syndrome but not with Behcet's disease in a Chinese Han population. Hum Immunol 71: 988-991.

Simon JD, Peles D, Wakamatsu K, Ito S. 2009. Current challenges in understanding melanogenesis: Bridging chemistry, biological control, morphology, and function. Pigment Cell Melanoma Res 22: 563-579.

Sommer L. 2011. Generation of melanocytes from neural crest cells. Pigment Cell Melanoma Res 24: 411-421.

Suzuki N, Suzuki T, Inagaki K, Ito S, Kono M, Fukai K, Takama H, Sato K, Ishikawa O, Abe M, et al. 2005. Mutation analysis of the ADAR1 gene in dyschromatosis symmetrica hereditaria and genetic differentiation from both dyschromatosis universalis hereditaria and acropigmentatio reticularis. J Invest Dermatol 124: 1186-1192.

Taieb A, Picardo M. 2009. Clinical practice. Vitiligo. N Engl J Med 360: 160-169.

Takahashi K, Yamanaka S. 2006. Induction of pluripotent stem cells from mouse embryonic and adult fibroblast cultures by defined factors. Cell 126: 663-676.

Tanimura S, Tadokoro Y, Inomata K, Binh NT, Nishie W, Yamazaki S, Nakauchi H, Tanaka Y, McMillan JR, Sawamura D, et al. 2011. Hair follicle stem cells provide a functional niche for melanocyte stem cells. Cell Stem Cell 8: 177-187.

Teodosio C, Garcia-Montero AC, Jara-Acevedo M, SanchezMunoz L, Pedreira CE, Alvarez-Twose I, Matarraz S, Morgado JM, Barcena P, Matito A, et al. 2013. Gene expression profile of highly purified bone marrow mast cells in systemic mastocytosis. J Allergy Clin Immunol 131: $1213-1224$.

Tobin DJ. 2011. The cell biology of human hair follicle pigmentation. Pigment Cell Melanoma Res 24: 75-88.

Tsao H, Chin L, Garraway LA, Fisher DE. 2012. Melanoma: From mutations to medicine. Genes Dev 26: 1131-1155.

van Bon BW, Gilissen C, Grange DK, Hennekam RC, Kayserili H, Engels H, Reutter H, Ostergaard JR, Morava E, Tsiakas K, et al. 2012. Cantu syndrome is caused by mutations in ABCC9. Am J Hum Genet 90: 1094-1101.

Wajapeyee N, Serra RW, Zhu X, Mahalingam M, Green MR. 2010. Role for IGFBP7 in senescence induction by BRAF Cell 141: 746-747.

Wang KC, Yang YW, Liu B, Sanyal A, Corces-Zimmerman R, Chen Y, Lajoie BR, Protacio A, Flynn RA, Gupta RA, et al. 2011. A long noncoding RNA maintains active chromatin to coordinate homeotic gene expression. Nature 472: 120-124.

Wang CQ, Akalu YT, Suarez-Farinas M, Gonzalez J, Mitsui H, Lowes MA, Orlow SJ, Manga P, Krueger JG. 2013. IL17 and TNF synergistically modulate cytokine expression while suppressing melanogenesis: Potential relevance to psoriasis. J Invest Dermatol 133: 2741-2752.

Wataya-Kaneda M, Tanaka M, Nakamura A, Matsumoto S, Katayama I. 2011. A topical combination of rapamycin and tacrolimus for the treatment of angiofibroma due to tuberous sclerosis complex (TSC): A pilot study of nine Japanese patients with TSC of different disease severity. Br J Dermatol 165: 912-916.

Watt B, Tenza D, Lemmon MA, Kerje S, Raposo G, Andersson L, Marks MS. 2011. Mutations in or near the transmembrane domain alter PMEL amyloid formation from functional to pathogenic. PLoS Genet 7: e1002286.

Wei AH, Li W. 2013. Hermansky-Pudlak syndrome: Pigmentary and non-pigmentary defects and their pathogenesis. Pigment Cell Melanoma Res 26: 176-192.

Wogelius RA, Manning PL, Barden HE, Edwards NP, Webb SM, Sellers WI, Taylor KG, Larson PL, Dodson P, You H, et al. 2011. Trace metals as biomarkers for eumelanin pigment in the fossil record. Science 333: 1622-1626.

Xing Q, Chen X, Wang M, Bai W, Peng X, Gao R, Wu S, Qian X, Qin W, Gao J, et al. 2005. A locus for familial generalized lentiginosis without systemic involvement maps to chromosome 4q21.1-q22.3. Hum Genet 117: 154-159.

Yakura H, Wakisaka A, Aizawa M, Itakura K, Tagawa Y. 1976. HLA-D antigen of Japanese origin (LD-Wa) and its association with Vogt-Koyanagi-Harada syndrome. Tissue Antigens 8: 35-42.

Yamada Y, Sawai S, Misawa S, Kanai K, Shibuya K, Mori M, Moriya J, Sogawa K, Yamamoto H, Beppu M, et al. 2013. Multiple angiogenetic factors are upregulated in POEMS syndrome. Ann Hematol 92: 245-248.

Yamaguchi Y, Hearing VJ. 2009. Physiological factors that regulate skin pigmentation. Biofactors 35: 193-199.

Yamaguchi Y, Itami S, Watabe H, Yasumoto K, Abdel-Malek ZA, Kubo T, Rouzaud F, Tanemura A, Yoshikawa K, Hearing VJ. 2004. Mesenchymal-epithelial interactions in the skin: increased expression of dickkopf1 by palmoplantar fibroblasts inhibits melanocyte growth and differentiation. J Cell Biol 165: 275-285.

Yamaguchi Y, Hearing VJ, Itami S, Yoshikawa K, Katayama I. 2005. Mesenchymal-epithelial interactions in the skin: Aiming for site-specific tissue regeneration. J Dermatol Sci 40: 1-9.

Zhang P, Liu W, Zhu C, Yuan X, Li D, Gu W, Ma H, Xie X, Gao T. 2012. Silencing of GPNMB by siRNA inhibits the formation of melanosomes in melanocytes in a MITFindependent fashion. PLoS ONE 7: e42955.

Zou YS, Milunsky JM. 2009. Developmental disability and hypomelanosis of Ito in a female with $7.3 \mathrm{Mb}$ de novo duplication of Xp11.3-p11.4 and random X inactivation. Am J Med Genet A 149A: 2573-2577. 


\section{$\&_{\mathrm{CSH}}^{\infty} \&$ Cold Spring Harbor

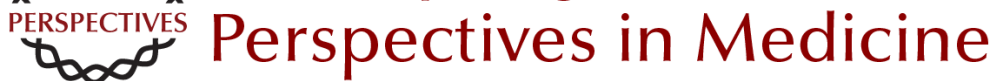

\section{Melanocytes and Their Diseases}

Yuji Yamaguchi and Vincent J. Hearing

Cold Spring Harb Perspect Med 2014; doi: 10.1101/cshperspect.a017046

Subject Collection The Skin and Its Diseases

Melanoma: Clinical Features and Genomic Insights

Elena B. Hawryluk and Hensin Tsao

Wound Healing and Skin Regeneration

Makoto Takeo, Wendy Lee and Mayumi Ito

The Dermal Papilla: An Instructive Niche for

Epithelial Stem and Progenitor Cells in

Development and Regeneration of the Hair Follicle Bruce A. Morgan

Immunology and Skin in Health and Disease Jillian M. Richmond and John E. Harris

Desmosomes: Regulators of Cellular Signaling and Adhesion in Epidermal Health and Disease Jodi L. Johnson, Nicole A. Najor and Kathleen J. Green

Markers of Epidermal Stem Cell Subpopulations in Adult Mammalian Skin Kai Kretzschmar and Fiona M. Watt

Psoriasis Paola Di Meglio, Federica Villanova and Frank O. Nestle

Cell Therapy in Dermatology Gabriela Petrof, Alya Abdul-Wahab and John A. McGrath
Modeling Cutaneous Squamous Carcinoma

Development in the Mouse

Phillips Y. Huang and Allan Balmain

Natural and Sun-Induced Aging of Human Skin Laure Rittié and Gary J. Fisher

Advanced Treatment for Basal Cell Carcinomas Scott X. Atwood, Ramon J. Whitson and Anthony E. Oro

Epidermal Polarity Genes in Health and Disease Frederik Tellkamp, Susanne Vorhagen and Carien M. Niessen

Induced Pluripotent Stem Cells in Dermatology:

Potentials, Advances, and Limitations Ganna Bilousova and Dennis R. Roop

The Genetics of Human Skin Disease Gina M. DeStefano and Angela M. Christiano

p53/p63/p73 in the Epidermis in Health and Disease

Vladimir A. Botchkarev and Elsa R. Flores

Diversification and Specialization of Touch

Receptors in Skin

David M. Owens and Ellen A. Lumpkin

For additional articles in this collection, see http://perspectivesinmedicine.cshlp.org/cgi/collection/ 